\title{
Response of a mixed native warm-season grass planting to nitrogen fertilization
}

\author{
WILLIAM A. BERG
}

The author is a soil scientist at the USDA-ARS Southern Plains Range Research Station, 2000 18th Street, Woodward, Okla. 73801 .

\begin{abstract}
Plant available nitrogen limits production of native warm-season grasses on marginal farmland in the Southern Plains. In this western Oklahoma study, $N$ was applied at $0,35,70$, or $105 \mathrm{~kg} \mathrm{~N}$ $\mathrm{ha}^{-1} \mathrm{yr}^{-1}$ to a mixed stand of blue grama (Bouteloua gracilis (H.B.K.) Lag. ex Griffiths), sideoats grama (B. curtipendula (Michx.) Torr.), little bluestem (Schizachyrium scoparium (Michx.) Nash), sand bluestem (Andropogon hallii Hack.), switchgrass (Panicum virgatum L.) and indian grass (Sorghastrum nutans (L.) Nash). The grass was established on sandy loam soil farmed an estimated 90 years. With near-normal precipitation the first year, production of perennial grasses increased linearly with $26 \mathrm{~kg}$ herbage produced $\mathrm{kg}^{-1} \mathrm{~N}$ applied. In drouth conditions, the second and third years, production averaged $10 \mathrm{~kg}$ herbage $\mathrm{kg}^{-1} \mathrm{~N}$ applied. The fourth and fifth year the stand was not fertilized and residual effects measured. Herbage production increased $10 \mathrm{~kg}$ for each $\mathrm{kg} N$ applied over the previous 3 years. Blue Grama made up much of this increased herbage production along with warm-season annuals (Panicum capillare $\mathbf{L}$. and Amaranthus retroflexus $\mathrm{L}$.). With increasing $\mathrm{N}$ rates the residual $\mathrm{N}$ effect increased the proportion of blue grama and decreased the proportion of taller perennial grasses. Thus, $\mathrm{N}$ fertilization of mixed native warm-season grass stands established on marginal farmland, typical of stands established on sandier soils under the USDA Conservation Reserve Program, can result in substantial herbage yield increases, however, some of the increased yield may be from weedy species.
\end{abstract}

Key Words: Southern Plains, marginal farmland, nitrogen use efficiency, blue grama, sideoats grama, warm-season annuals

Native warm-season grass mixtures have been established in USDA Conservation Reserve Program (CRP) plantings on several million hectares of highly erodible marginal farmland in the Southern Great Plains. Upon termination of CRP contracts, the major options will be to graze the grass or return the land to wheat (Triticum aestivum $\mathrm{L}$.) or sorghum (Sorghum bicolor (L.) Moench) production. In some cases, this land use decision will depend upon the productivity of the grass. The grass mixtures often include blue grama (Bouteloua gracilis (H.B.K.) Lag. ex Griffiths), sideoats grama (B. curtipendula (Michx.) Torr.), little

The author wishes to thank John Loch for assistance in the field work Tom Popham for statistical analyses.

Manuscript accepted 4 Jul. 1994. bluestem (Schizachyrium scoparium (Michx.) Nash), sand bluestem (Andropogon hallii Hack.), switchgrass (Panicum virgatum L.) and indian grass (Sorghastrum nutans (L.) Nash).

Grass production on marginal farmland in the Southern Plains has been shown to be limited by $N$ availability (Herndon 1974, Salih and Burzlaff 1975, Berg 1990) following years of cultivation and erosion that reduced organic $\mathrm{C}$ and $\mathrm{N}$ in these soils (Haas et al. 1957). Nitrogen fertilization of introduced warm-season grasses is a common practice in the region (Dahl and Cotter 1984, Berg 1990). However, native warm-season grasses are seldom $\mathrm{N}$ fertilized. This may be for a number of reasons including:

1) research showing increased cattle gain with $N$ fertilization of native rangeland dominated by warm-season grasses is not economically attractive (Huffine and Elder 1960, Donart et al. 1978);

2) weedy species increase with $N$ fertilization (Huffine and Elder 1960, Launchbaugh 1962, Petit and Deering 1974); and

3) the taller native grasses will not persist under intensive grazing commonly used on $\mathrm{N}$-fertilized introduced grasses (Bidwell 1992).

This study was designed to determine the response of a native mixed grass planting on marginal farmland to 3 rates of $\mathrm{N}$ applied at April greenup or 3 and 6 weeks later. Time of $\mathrm{N}$ application was included as a variable to investigate the effect on herbage production and species composition, particularly weedy annuals. Nitrogen was applied at rates estimated to represent minimum, moderate, and maximum practical applications. A record drouth during the second and third years of the study provided an opportunity to observe the response of the planting to the combination of $\mathrm{N}$ fertilization and drouth.

\section{Materials and Methods}

This field study was conducted from 1989 through 1993 at the USDA-ARS Southern Plains Range Research Station near Woodward in northwestern Oklahoma. The land had been cultivated an estimated 90 years since the native mixed-grass prairie was plowed. Plots were on Enterprise fine sandy loam (coarsesilty, mixed thermic Typic Ustochrepts) which contained an average of $4.8 \mathrm{~g}$ organic $\mathrm{C} \mathrm{kg}^{-1}$ (Mebius method, Nelson and Sommers 1982), $0.57 \mathrm{~g} \mathrm{~N} \mathrm{~kg}^{-1}$ (Kjeldahl procedure, Bremner and Mulvaney 1982), and pH of $7.0(1: 1, \mathrm{wt}: \mathrm{wt})$ in the surface $15 \mathrm{~cm}$. Nitrate tested low at $2 \mathrm{mg} \mathrm{N} \mathrm{kg}^{-1}$ (calcium sulfate extraction, Hanlon and Johnson 1983) as did ammonium at $5 \mathrm{mg} \mathrm{N} \mathrm{kg-1}$ 
(steam distillation, Kenney and Nelson 1982). Phosphorus tested adequate at $50 \mathrm{mg} \mathrm{P} \mathrm{kg}^{-1}$ (Bray \#1, Hanlon and Johnson 1983) as did potassium at $430 \mathrm{mg} \mathrm{K} \mathrm{kg}^{-1}$ (ammonium acetate extraction, Hanlon and Johnson 1983).

A seed mixture of the following species and rates was drilled in April 1987: 'Hachita' blue grama $30 \mathrm{pls} \mathrm{m}$ ', 'El Reno' sideoats

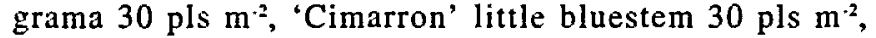
'Woodward' sand bluestem $12 \mathrm{pls} \mathrm{m}^{-2}$, 'Blackwell' switchgrass 20 pls $\mathrm{m}^{-2}$, and 'Cheyenne' indian grass $20 \mathrm{pls} \mathrm{m}^{-2}$. Grass establishment was good with sideoats grama and blue grama the dominant grasses established. The stand was not grazed or hayed in 1987 or 1988, in April 1989 the aftermath was mowed and left in place.

In April 1989 an $18 \times 60$-m study area was selected and treatments randomly assigned to $3 \times 9$-m plots within each of 4 blocks and repeated on the same plot for 3 years $(1989,1990,1991)$. Treatments were a check $(0 \mathrm{~N})$ and factorial combination of $3 \mathrm{~N}$ application dates (early April, late April, and mid May) and $3 \mathrm{~N}$ application rates $\left(35,70\right.$, and $\left.105 \mathrm{~kg} \mathrm{ha}^{-1}\right)$. The $\mathrm{N}$ was broadcast as ammonium nitrate.

In this area, these warm-season native grasses commonly start to greenup in carly April and have 5 to $10 \mathrm{~cm}$ of new growth by mid-May. Herbage production was determined by using a sicklebar mower to cut a $1.25 \times 7.75-\mathrm{m}$ area within each plot, weighing, subsampling, and drying at $57^{\circ} \mathrm{C}$. Harvests at a cutting height of $5 \mathrm{~cm}$ were made on 18 July 1989, 5 July 1990, and 27 June 1991. A $0.2 \times 5-\mathrm{m}$ area was hand clipped in each plot on 20 July 1989 and the harvest separated into annuals and perennials. Dormant season aftermath harvests were made in early winter 1989 and 1990. A dormant season harvest was not made in 1991 since there was no regrowth in this drouth year. After each sampling the entire plot area was harvested and herbage discarded off the plat area.

Precipitation in the October through September period was 645 $\mathrm{mm}$ in $1988-89,340 \mathrm{~mm}$ in $1989-90,355 \mathrm{~mm}$ in $1990-91,585$ $\mathrm{mm}$ in 1991-92, and $640 \mathrm{~mm}$ in 1992-93. The 1914-1993 average annual precipitation was $593 \mathrm{~mm}$; precipitation for 1990 and 1991 was the least for any 2 consecutive years within this period. Precipitation for 3 years the study was $\mathrm{N}$ fertilized is shown in Fig. 1 .

Because of the drouth, the study was not fertilized in 1992 and

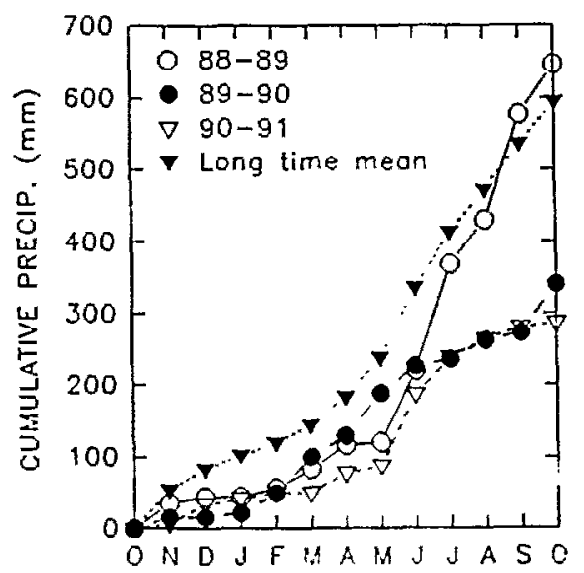

Fig. 1. Precipitation at Woodward, Okla. was below normal in October through March the first 3 years of the study and much below normal for the second and third growing seasons. the following sampling done in mid July 1992 and 1993. Herbage production by species or groupings of species was measured by hand clipping at $2 \mathrm{~cm}$, two $0.5 \times 2-\mathrm{m}$ quadrats in each plot and drying at $57^{\circ} \mathrm{C}$. The remaining herbage in each plot was not cut after the 1992 sampling so as to allow seed production by weedy annuals. The aftermath was mowed in March 1993 and left in place.

Frequency by species rooted within each quadrat was determined in 1992 within fifty $0.1 \mathrm{~m}^{2}$ quadrats within each plot, quadrat placement was at $0.25-\mathrm{m}$ intervals along two $6-\mathrm{m}$ poles randomly placed length wise in the plots. Frequency sampling was also extended to four $3 \times 9$-m plots each adjacent to 1 of the 4 blocks but outside of the original plot area. These additional plots received no $\mathrm{N}$ treatments and were not harvested during the 1989,1990 , or 1991 growing seasons, these plots were mowed in the early spring of each year and the cuttings left in place.

Analysis of variance was used to determine effect of $\mathrm{N}$ application dates on herbage production. Herbage yields from the earliest 1989, 1990, and $1991 \mathrm{~N}$ application dates were partitioned into linear, quadratic, cubic, and residual components by year, only regressions significant at the 0.05 level are reported. Mean herbage yield from all 3 times of $\mathrm{N}$ application treatments werc used to calculate residual $\mathrm{N}$ effects in 1992 and 1993 as there was no significant difference among $\mathrm{N}$ application dates these years.

\section{Results}

Herbage yield in 1989 increased linearly with $\mathrm{N}$ applied (Fig. 2.). The slope of the regression line (Fig. 2) is the efficiency of fertilizer $N$ to increase herbage yield. Thus for 1989 , slope $=26$ $\mathrm{kg}$ herbage yield $\mathrm{kg}^{-1} \mathrm{~N}$ applied. In 1989, precipitation was below normal until June rain of $150 \mathrm{~mm}$ brought accumulative precipitation to near normal (Fig. 1) and enhanced growth of the warmseason grasses. Annuals comprised an average of $1.9 \%$ of the herbage yield in July 1989 with nonsignificant differences among $\mathrm{N}$ treatments.

Drouth in 1990 and 1991 (Fig. 1) drastically reduced herbage yields on all treatments and resulted in an average of $10 \mathrm{~kg}$ herbage yield $\mathrm{kg}^{-1} \mathrm{~N}$ applied (Fig. 2). Or if a probability of $<0.10$ is accepted, the relationship in 1991 is curvilinear (quadratic) with smaller yield increases per $\mathrm{kg} \mathrm{N}$ applied as $\mathrm{N}$ rates increased. Grass in $N$ treatments wilted and leaf tips burned during summer drouths, whereas unfertilized grass was only slightly affected. Herbage production by annuals was not determined in 1990 and 1991 since by inspection annuals made up less than $2 \%$ of the mass of herbage harvested.

Nitrogen application in April 1989 or early April 1990 produced greater July herbage yields than mid May application in 2 of the 3 years $\mathrm{N}$ was applied (Table 1). However, total yearly herbage yield was not affected by time of $\mathrm{N}$ application. Perennial grasses comprised most of the herbage yield in 1989 , 1990, and 1991 following considerably below normal October through March precipitation prior to these 3 growing seasons (Fig. 1).

Regrowth after the 27 July 1991 harvest was negligible and by April 1992 it was obvious that many sideoats grama plants were dead. As a consequence, the plots were not fertilized in 1992 and the residual effect of the previous 3 years of $\mathrm{N}$ fertilization was measured on herbage production in 1992 and 1993. The residual effect over 2 years was directly proportional to the amount of $\mathrm{N}$ 


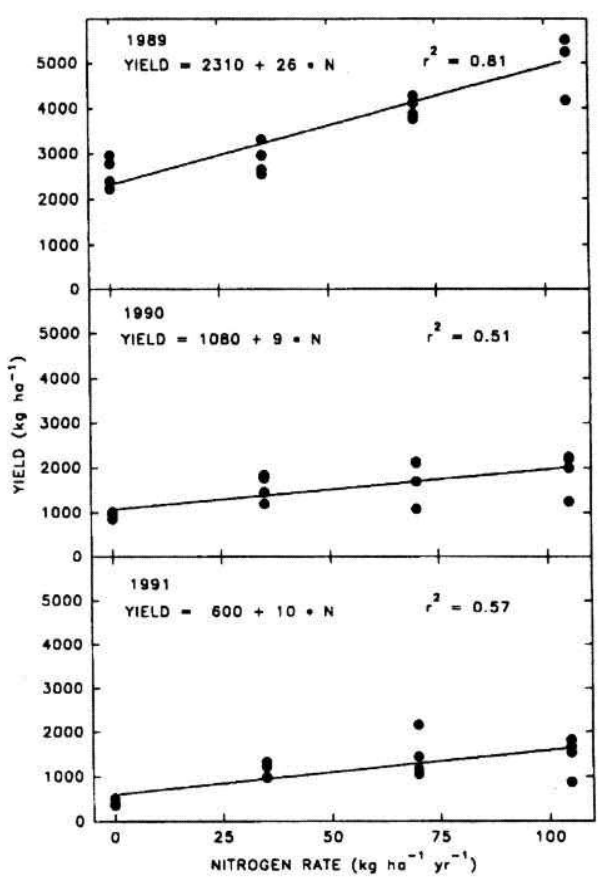

Fig. 2. Herbage yields from a mixed native grass planting in western Oklahoma as related to the rate of $\mathbf{N}$ applied each of 3 years.

applied, with herbage production increasing $10 \mathrm{~kg}$ for each $\mathrm{kg} \mathrm{N}$ applied over the previous 3 years. Herbage production $\left(\mathrm{kg} \mathrm{ha}^{-1}\right)$ in $1992=1,070+6.8 \cdot$ total $\mathrm{N}$ applied $1989-91, r^{2}=0.78^{* *}$. Blue grama made up about one-half of the increased production in 1992, the remainder was largely warm-season annuals, predominately annual panicum (Panicum capillare L.) and pigweed (Amaranthus retroflexus L.) (Fig. 3).

The residual $\mathrm{N}$ response in 1993 was less, with herbage yield = $1,150+3.6 \cdot$ total $\mathrm{N}$ applied $1989-91 r^{2}=0.76^{* *}$. Blue grama made up nearly all this increased herbage production (Fig. 3). Annuals were unimportant, and production by sideoats grama decreased at the higher residual $\mathrm{N}$ rates (Fig. 3). Western ragweed (Ambrosia psilostachya DC.) was the major herbage producer among the other perennials on the higher residual $\mathrm{N}$ rate treatments.

The residual effects were also shown in species frequency determined in 1992 when blue grama and annuals increased and sideoats grama decreased as $\mathrm{N}$ rates increased (Fig. 4). Frequency of tall grasses (sand bluestem, little bluestem, switchgrass, indian grass) decreased and frequency of blue grama and annuals increased on unfertilized plots harvested annually in mid-summer as compared with unfertilized plots that were not harvested in

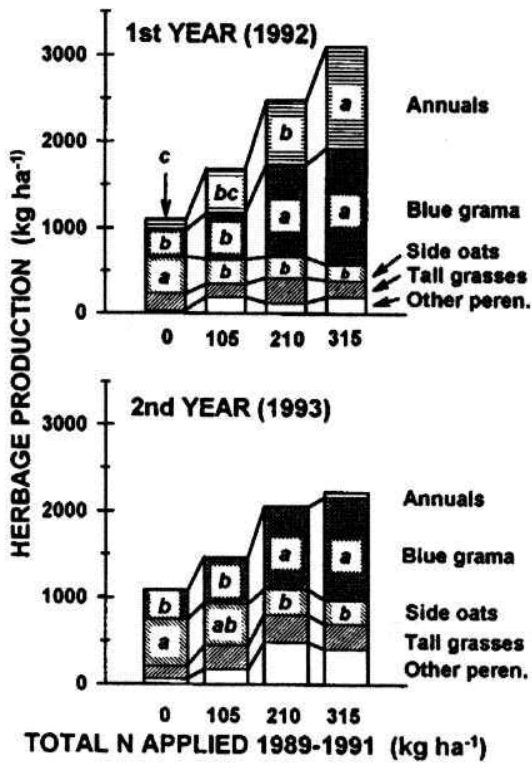

Fig. 3. First and second year residual effects on herbage production by species following $\mathbf{N}$ application the previous 3 years to a mixed warm-season grass planting. Herbage production across $\mathbf{N}$ rates within a species and year indicated by a common letter or no letter are not significantly $(P>0.05)$ different.

mid summer (Fig. 4).

\section{Discussion}

Grazing is the major use of native grass seedings in the Southern Plains. Clipping studies, such as reported here, may provide information, but must be used with caution when extrapolating to grazing. This is because $\mathrm{N}$ is recycled with grazing (Russelle 1992), herbage production may not be closely correlated with cattle gains (Rogler and Lorenz 1974), and plant physiological responses may be different to clipping than grazing.

Herbage production on the unfertilized native grass planting in this study averaged $1,230 \mathrm{~kg} \mathrm{ha}^{-1} \mathrm{yr}^{-1}$. Most of this production was by perennial grasses. This production is about half of that suggested by SCS (Cole et al. 1966) standards for the loamy prairie site on the Enterprise soil series, but is near the $1,200 \mathrm{~kg} \mathrm{ha}^{-1} \mathrm{yr}^{-1}$ forage production measured over 8 years on moderately stocked native range in the area (McIlvain and Shoop 1961). Thus, forage production on the unfertilized native grass planting on marginal farmland may be similar to production on native rangeland that has a history of heavy grazing by domestic livestock.

Table 1. Herbage yields of a native grass planting in western Oklahoma as affected by time of $\mathrm{N}$ application. Herbage yields are averaged over $3 \mathrm{~N}$ rates.

\begin{tabular}{|c|c|c|c|c|c|c|c|}
\hline \multirow{3}{*}{$\begin{array}{l}\text { Time of } \\
\text { application }\end{array}$} & \multicolumn{5}{|c|}{ Year of $\mathrm{N}$ application and 1 st harvest date } & \multicolumn{2}{|c|}{ Residual } \\
\hline & \multicolumn{2}{|c|}{1989} & \multicolumn{2}{|c|}{1990} & \multirow{2}{*}{$\frac{1991}{27 \mathrm{Jun} .}$} & \multirow{2}{*}{$\frac{1992}{21 \mathrm{Jul} .}$} & \multirow{2}{*}{$\frac{1993}{21 \mathrm{Jul} .}$} \\
\hline & $18 \mathrm{Jul}$. & Total & 5 Jul. & Total & & & \\
\hline & & . & $-\cdots$ & $-\cdots$ & $\ldots \ldots$ & & \\
\hline early Apr. & $2,820 a^{*}$ & $4,040 \mathrm{a}$ & $1,300 \mathrm{a}$ & $1,750 \mathrm{a}$ & $1,350 \mathrm{a}$ & $2,260 \mathrm{a}$ & $1.900 \mathrm{a}$ \\
\hline late Apr. & $2,900 \mathrm{a}$ & $4,130 \mathrm{a}$ & $970 \mathrm{~b}$ & $1,410 \mathrm{a}$ & $1,390 \mathrm{a}$ & $2,770 \mathrm{a}$ & $1,910 \mathrm{a}$ \\
\hline \multirow[t]{2}{*}{ mid May } & $2,230 \mathrm{~b}$ & $3,710 \mathrm{a}$ & $990 \mathrm{~b}$ & $1,400 \mathrm{a}$ & $1,430 \mathrm{a}$ & $2,370 \mathrm{a}$ & $1,890 \mathrm{a}$ \\
\hline & 8 & 7 & 12 & 12 & 11 & 19 & 7 \\
\hline
\end{tabular}

*Yields within a column designated with a common letter are not significantly $(P>0.05)$ different. 


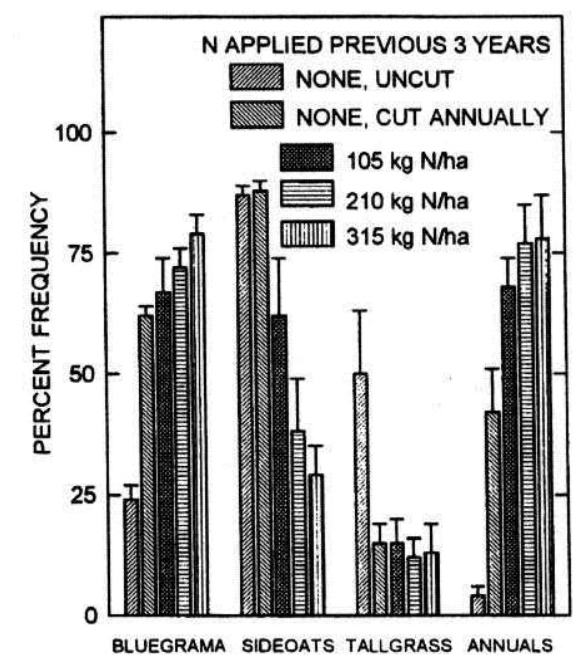

Fig. 4. Plant frequency within $0.1 \mathrm{~m}^{2}$ quadrats the year 1992 following 3 years of $\mathrm{N}$ treatments on a mixed warm-season grass planting. Vertical, capped lines equal $+\mathrm{SE}$.

Nitrogen fertilization over 3 years increased herbage yield by an average of $15 \mathrm{~kg}$ herbage $\mathrm{kg}^{-1} \mathrm{~N}$ applied (Fig. 2). Adding the residual effect (Fig. 3) gives an overall $\mathrm{N}$ use efficiency of $25 \mathrm{~kg}$ herbage production $\mathrm{kg}^{-1} \mathrm{~N}$ applied. This $\mathrm{N}$ fertilizer use efficiency is within the range of 10 to $34 \mathrm{~kg}$ herbage produced $\mathrm{kg}^{-1} \mathrm{~N}$ applied for cool-season- grasses (Wedin 1974), and 15 to 40 for warm-season grasses (Wilkinson and Langdale 1974, Tucker and Murdock 1984). However, comparisons should be made with caution since the maturity of grass when harvested can greatly influence herbage production, and residual effects were not accounted for in the cited studies. The substantial herbage production response to residual $\mathrm{N}$ in this study is apparently a reflection of limited herbage production on $\mathrm{N}$-fertilized treatments in drouth conditions in 1990 and 1991.

Herbage production by weedy annuals was negligible on all $\mathrm{N}$ treatments in 1989, 1990, and 1991 following much below normal October through March precipitation. This finding is in contrast to research in New Mexico where annuals increased with $\mathrm{N}$ fertilization with drouth conditions (Fulgham et al. 1977).

Weedy annual production in 1992 (Fig. 3) was greatly enhanced by the previous 3 years of $\mathrm{N}$ fertilization. This finding is in agreement with studies showing an increase in production of annuals with $\mathrm{N}$ fertilization of native warm-season grasses (Huffine and Elder 1960, Launchbaugh 1962). In 1993, weedy annual production was small or negligible regardless of the previous $\mathrm{N}$ treatments. Overall, enhanced production of weedy annuals following $\mathrm{N}$ fertilization appears to be dependent upon both the timing and amount of precipitation. Annual bromes (Bromus spp.) were not important herbage producers in our study, but would be expected to be important with $\mathrm{N}$ fertilization and normal precipitation patterns (Lauchbaugh 1962). In the longer term, western ragweed, a perennial may be more of a problem in $\mathrm{N}$-fertilized native grass plantings than annuals. Blue grama increased and taller warm-season grasses decreased with the combination of $\mathrm{N}$ fertilization and growing season defoliation in this study.

Overall, this study indicates that herbage production is limited by $\mathrm{N}$ availability to native warm-season grasses established on marginal farmland typical of much of the sandier land now in the Conservation Reserve Program in the Southern Plains. Nitrogen fertilization increased herbage production with a fertilizer $\mathrm{N}$ use efficiency equal to or somewhat less than that on introduced grasses in the area (Berg 1990) and other warm-season grasses in the southeastern U.S. (Wilkinson and Langdale 1974).

\section{Literature Cited}

Berg, W.A. 1990. Old World bluestem response to nitrogen fertilization. J. Range Manage. 43:265-270.

Bidwell, T.G. 1992. Differences between range and introduced pasture management. OSU Extension Facts 2867. Coop. Ext. Ser. Oklahoma State University, Stillwater, Okla

Bremner, J.M., and C.S. Mulvaney. 1982. Nitrogen-total, p. 595-616. In: A.L. Page (ed.). Methods of soil analysis. Part 2. Amer. Soc. Agron. Madison, Wis.

Cole, E.L., A.J. Conradi, and C.E. Rhoads. 1966. Soil survey of Ellis County Oklahoma. USDA-SCS.

Dahl, B.E., and P.F. Cotter. 1984. Management of weeping lovegrass in west Texas. Range and Wildlife Management Note 5. Texas Tech Univ., Lubbock, Tex.

Donart, G.B., E.E. Parker, R.D. Pieper, and J.D. Wallace. 1978. Nitrogen fertilization of livestock grazing on blue grama rangeland, p. 614-615. In: D.N. Hyder (ed.) Proc. First Int. Rangeland Congress., Society for Range Management, Denver, Colo.

Fulgham, K.O., G.B., Donart, R.A. Pieper, M. Lentner and D.D. Dwyer. 1977. Effects of types and rates of nitrogen fertilizer on range herbage production under drought conditions. New Mexico State Univ. Agr. Exp. Sta. Res. Rep 343. Las Cruces, N.M.

Haas, H.J., C.E. Evans, and E.F. Miles. 1957. Nitrogen and carbon changes in Great Plains soils as influenced by cropping and soil treatments. USDA Tech. Bull. 1164., Washington, D.C.

Hanlon, E., and G. Johnson. 1983. Procedure for soil, forage, and water testing. OSU Extension Facts 2901. Coop. Ext Ser. Oklahoma State University, Stillwater, Okla.

Herndon, E.B. 1974. Nitrogen improves pasture production. Noxious Brush and Weed Control Highlights 5:7. Texas Tech Univ., Lubbock, Tex.

Huffine, W.W., and W.C. Elder. 1960. Effects of fertilization on native grass pastures in Oklahoma. J. Range Manage. 13:34-36.

Launchbaugh, J.L. 1962. Soil fertility investigations and effects of commercial fertilizers on reseeded vegetation in west-central Kansas. J. Range Manage. 15:27-34.

Kenney, D.R., and D.W. Nelson. 1982. Nitrogen-inorganic forms, p. 643698. In: A.L. Page (ed.) Methods of soil analysis, Part 2. Amer. Soc. Agron. Madison, Wis.

McIlvain, E.H., and M.C. Shoop. 1961. Stocking rates and grazing systems for producing forage and beef on sand sage rangelands. Unpublished progress report Southern Plains Range Res. Sta. Woodward, Okla. 68 p+appendix.

Nelson, D.W., and L.E. Sommers. 1982. Total carbon, organic carbon, and organic matter, p. 539-579. In: A.L. Page (ed.) Methods of soil analysis, Part 2. Amer. Soc. Agron. Madison, Wis.

Pettit, R.D., and D.W. Deering. 1974. Yield and protein content of sandyland range forages as affected by three nitrogen fertilizers. J. Range Manage. 27:211-213.

Russelle, M.P. 1992. Nitrogen cycling in pasture and range. J. Prod. Agr. 5:13-23.

Rogler, G.A., and R.J. Lorenz. 1974. Fertilization of mid-continent range plants, p. 231-254. In: D.A. Mays (ed.). Forage fertilization. Amer. Soc. Agron. Madison, Wis.

Salih, M., and D.F. Burzlaff. 1975. Fertilization increased indian grass production. Noxious Bursh and Weed Control Highlights 6:28. Texas Tech Univ., Lubbock, Tex.

Tucker, B.B., and L.W. Murdock. 1984. Nitrogen use in south central states, p. 735-749. In: R.D. Hauck (ed.) Nitrogen in crop production. Amer. Soc. Agron. Madison, Wis.

Wedin, W.F. 1974. Fertilization of cool-season grasses, p. 95-118. In: D.A. Mays (ed.) Forage fertilization. Amer. Soc. Agron. Madison, Wis.

Wilkinson, S.R., and G.W. Langdale. 1974. Fertility needs of the warm-season grasses, p. 119-145. In: D.A. Mays (ed.) Forage fertilization. Amer. Soc. Agron. Madison, Wis. 